\title{
U.S. Geological Survey Information Sources
}

As the Nation's largest water, earth, and biological science and civilian mapping agency, the U.S. Geological Survey (USGS) works in cooperation with more than 2,000 organizations across the country to provide reliable, impartial scientific information to resource managers, planners, and other customers. This information is gathered in every State by USGS scientists to minimize the loss of life and property from natural disasters, to contribute to the conservation and the sound economic and physical development of the Nation's natural resources, and to enhance the quality of life by monitoring water, biological, energy, and mineral resources.

\section{Natural Science Information}

The USGS Earth Science Information Centers (ESIC) offer nationwide information and sales services for products about mapping and natural resources. The ESICs provide information about geologic, hydrologic, cartographic, and biologic topics. A full array of digital data and information products is also available in a variety of formats. Visit the USGS World Wide Web home page for an exploration of earth and biological sciences at www.usgs.gov.

The USGS, in cooperation with State agencies and universities, coordinates a national network of State ESICs that provide State and local information about natural science products and services.

\section{Many of the State ESICs sell USGS} products. A list of State ESICs can be obtained by calling 1-888-ASK-USGS or by visiting the ASK USGS Web site at ask.usgs.gov.

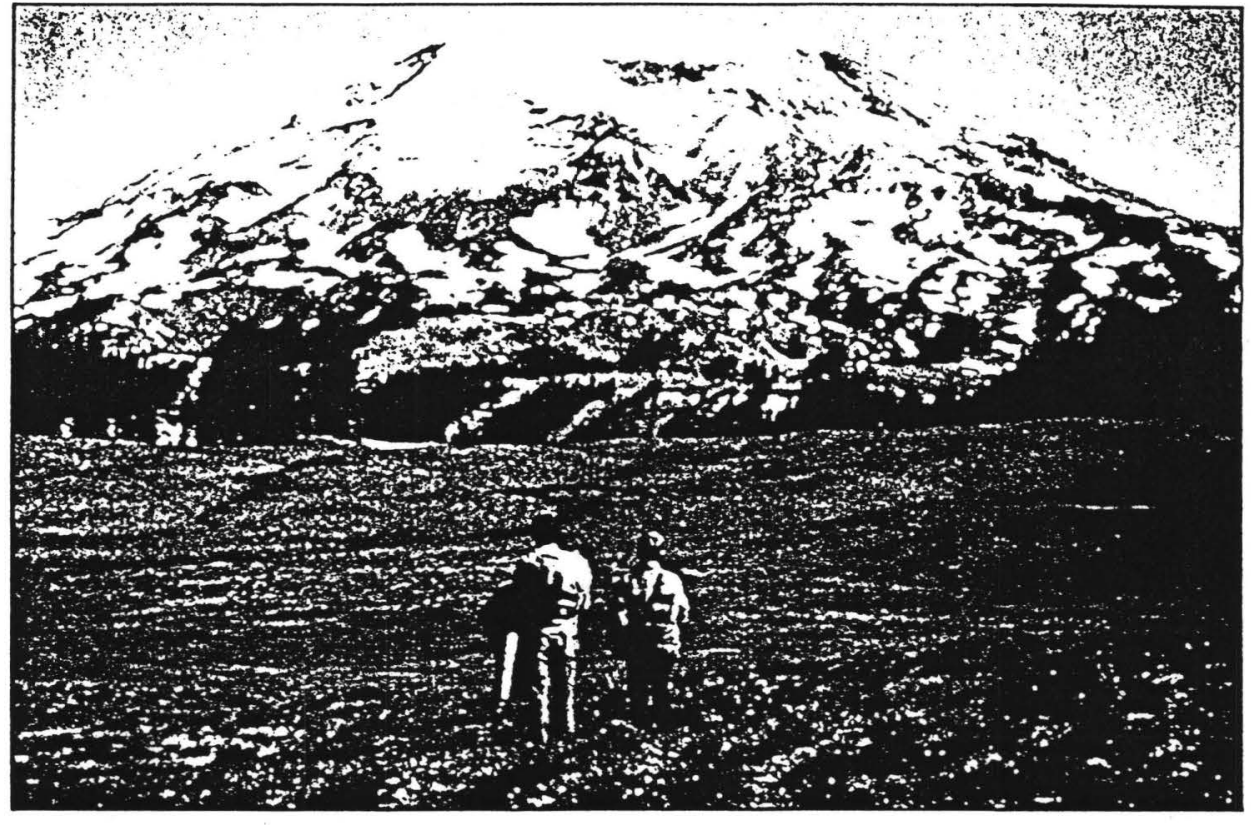

USGS Business Partners are private retailers of USGS products who sell maps, digital cartographic data, and aerial photographs. You can find lists of Business Partners by going online at mapping.usgs.gov/www/partners/ bpmain.html under "Find Retailers" or by calling 1-888-ASK-USGS.

ESICs can fill orders for custom products, such as aerial photographs and digital orthophoto quadrangles, digital cartographic data, and geographic names data.

ESICs can also provide information about natural science materials from many public and private producers in the United States by using online information retrieval systems.

For further information, contact or visit any of the following ESICs or call 1-888-ASK-USGS.
Anchorage-ESIC 4230 University Dr., Rm. 101 Anchorage, AK 99508-4664

Phone: 907-786-7011

Fax: 907-786-7050

E-mail: gfdurocher@usgs.gov

Denver-ESIC

Box 25286, Bldg. 810

Denver, CO 80225

Phone: $303-202-4200$

Fax: 303-202-4188

E-mail: infoservices@usgs.gov

Menlo Park-ESIC 345 Middlefield Rd., MS 532

Menlo Park, CA 94025-3591

Phone: $650-329-4309$

Fax: $650-329-5130$

*TDD: 650-329-5092

E-mail: wmcesic@usgs.gov 
Reston-ESIC

507 National Center

Reston, VA 20192

Phone: 703-648-5953

Fax: 703-648-5548

*TDD: 703-648-4119

E-mail: ask@usgs.gov

Rolla-ESIC

1400 Independence Rd., MS 231

Rolla, MO 65401-2602

Phone: $573-308-3500$

Fax: 573-308-3615

*TDD: 573-341-2716

E-mail: mcmcesic@usgs.gov

Sioux Falls-ESIC

EROS Data Center

Sioux Falls, SD 57198-0001

Phone: 605-594-6151

Fax: 605-594-6589

*TDD: 605-594-6933

E-mail: custserv@usgs.gov

\section{Spokane-ESIC}

U.S. Post Office Building, Rm. 135

904 West Riverside Ave.

Spokane, WA 99201-1088

Phone: 509-368-3130

Fax: 509-368-3194

*TDD: 509-368-3133

E-mail: esnfic@usgs.gov

Washington, DC-ESIC

U.S. Department of the Interior Building 1849 C Street, NW., Rm. 2650

Washington, DC 20240

Phone: $202-208-4047$

Fax: 202-208-6297

*TDD: 202-219-1510

E-mail: ask@usgs.gov

Information requests for water resources topics may also be directed to:

Phone: 1-888-ASK-USGS

E-mail: h2oinfo@usgs.gov

\section{Map Sales}

Use the information below to obtain free map indexes and catalogs and to order topographic maps or any of the wide variety of thematic maps available from the USGS:

USGS Information Services

Box 25286

Denver, CO 80225

Phone: $303-202-4700$ or

1-888-ASK-USGS

Fax: 303-202-4693

\section{Book Sales}

To order USGS book catalogs titled "Publications of the U.S. Geological Survey" (catalogs include references that date back to 1879) and all technical reports, books, popular science publications, and posters, use the address listed below:

USGS Information Services

Box 25286

Denver, CO 80225

Phone: $303-202-4700$ or

1-888-ASK-USGS

Fax: 303-202-4693

To order USGS open-file reports, contact:

USGS Information Services

Open-File Reports

Box 25286

Denver, CO 80225

Phone: $303-202-4200$

Fax: 303-202-4693
To get on the mailing list for the free catalog "New Publications of the U.S. Geological Survey," send your name and address to:

USGS New Publications

903 National Center

Reston, VA 20192

E-mail: pburnworth@usgs.gov

The catalog can also be accessed through the World Wide Web at pubs.usgs.gov/ publications/.

\section{For More Information}

For information on these and other USGS products and services, call 1-888ASK-USGS, use the Ask.USGS fax service, which is available 24 hours a day at 703-648-4888, or visit the general interest publications Web site on mapping, geography, and related topics at mac.usgs.gov/mac/isb/pubs/ pubslists/index.html.

Please visit the USGS home page at www.usgs.gov. 